\title{
"Make" or "Buy" the Choice of Governance Modes for Corporate Social Responsibility Projects from a Stakeholder Management Perspective
}

\author{
Francesco Gangi ${ }^{1}$, Eugenio D’Angelo ${ }^{2}$ \\ ${ }^{1}$ Department of Management, University of Campania 'Luigi Vanvitelli”, Capua, Italy \\ ${ }^{2}$ Department of Economics and Legal Studies, Pegaso Telematic University, Naples, Italy \\ Correspondence: Francesco Gangi, Department of Management, University of Campania, Capua, Italy.
}

Received: June 20, 2017

doi:10.5539/ibr.v10n8p80

\author{
Accepted: July 10, 2017 \\ Online Published: July 11, 2017
}

URL: https://doi.org/10.5539/ibr.v10n8p80

\begin{abstract}
The organization of corporate social responsibility (CSR) initiatives deals with a "make" or "buy" trade-off among in-house solutions instead of a partial (collaboration) or total (outsourcing) externalization of such activities. This article aims to advance the knowledge of the criteria underlying the governance modes of CSR. In particular, integrating the organizational economics with the insights provided by the stakeholder management, the study deepens the reasons why primary stakeholders, such as human resources (HR) and customers, may affect the choice to internalize the governance of CSR projects. Findings are consistent with the theoretical framework. In fact, internal solutions are more likely for CSR initiatives addressed to HR and customers. Given the direct linkage of these stakeholders with the achievement of the company's mission, results corroborate the concept of closeness of CSR actions with respect to the firm's core business as driver of in-house projects.
\end{abstract}

Keywords: CSR, stakeholder management, governance modes

\section{Introduction}

Over the years, companies have had to face a growing demand for a greater social responsibility coming from various stakeholder groups. Simultaneously, it has increased the need for a more stringent scrutiny of CSR initiatives. Apparently antithetical, the mentioned pressures have triggered a broad debate since the well-known Friedman's position (1970) on CSR as an agency problem (McWilliams et al., 2005; Harris \& Freeman, 2008; Salazar \& Husted, 2008).

The prolonged effects of the last financial downturn have exacerbated the scenario described by Carroll (2000) of a persistent challenge for firms of the new millennium to concurrently be profitable, obey the law and be engaged in ethical behaviour and philanthropy. In fact, the global recession of 2008-2009 posed corporations in front of the very real question of whether they could maintain the commitment to CSR while retreating into core activities (Bansal et al., 2015), a topic which concurs to make even more artificial the division between economic and noneconomic dimensions of corporate social responsibility (Carvalho et al., 2014). Alternatively, the moral imperative, the good reputation or the license to operate (Porter \& Kramer, 2006) may appear too vague or distant justifications with respect to the research for equilibrium between short-term costs and long-term benefits of CSR. After all, no theory on CSR decision-making may endure if it contradicts the fundamental principle of wealth creation by the firm (Husted et al., 2010).

From an organizational point of view, the question can be seen as a trade-off between leveraging on internal resources and resorting to the market. In this perspective, the article aims at advancing the comprehension of organizational economics of CSR, focusing on the option between the internalization or the externalization of socially responsible projects. In particular, this study intends to verify if for initiatives targeted to primary stakeholders, such as human resources (HR) and customer, it's more likely the adoption of in-house governance modes instead of external solutions. Once these stakeholders are confirmed as drivers to "make" CSR, given their direct linkage with the corporate core mission (Carroll 1993; Clarkson 1995), the concept of centrality of CSR actions (Burke \& Logsdon, 1996; Husted 2003; Husted et al., 2010) may be further strengthened as a justification for internalizing CSR activities in order to optimize costs and strategic benefits. 


\subsection{Governance Modes of Strategic CSR}

This subsection carries out an overview of the literature which allows to set the topic of governance modes within the theoretical framework of strategic CSR and organizational economics (Husted et al., 2010). In particular, over the years, the study of CSR has been frequently oriented by the fundamental question if the social responsibility is complementary or in conflict with the economic objectives of firm (Peloza, 2006). In other words, do "firms do well by doing good"? (McWilliams et al., 2005). This general the me has spurred theoretical and practical topics well summarized in the query posed by Burke and Logsdon (1996) about the search for the conditions through which a firm can jointly serve its own strategic business interests and the societal interests of its stakeholders.

The last financial crisis has renewed the debate on limits and requirements of a strictly shareholder view, giving new force and a renewed interest to investigate the priorities a company should comply. The social responsibility of a corporation and the related efforts are themselves values in a modern economy. However, between the theoretical approach and the practical application, the risk of a gap is still relevant, as confirmed by the financial constraints (UN-Global Compact and Accenture on Sustainability, 2013; Bansal et al., 2015), which push for a business case approach to CSR (Nijhof et al., 2007; Kurucz et al., 2008).

Despite theoretical and empirical unresolved issues, studies on the strategic approach to CSR have tried to provide a framework for the laudable attempt to meet the respect of CSR with the creation of a competitive advantage. As argued by Carvalho (Carvalho et al., 2014), the development of a strategic orientation aimed at "economizing" CSR represents a condition for organizational continuity. This is consistent with the reconfiguration of the same concept of social responsibility from a "non-market" activity into a more complex "social- market" activity (Husted \& Hallen, 2007) enabling new windows of opportunity for the creation of an enlarged value (Werther \& Chandler, 2010). From this perspective, the design of CSR initiatives needs to be integrated with the broader corporate strategy. Given resources and objectives, the assumption is that the firm is generally unable to meet any social instances. Consequently, the emerging of a prioritization process of CSR domains overlaps with a stakeholder management approach (Bansal et al., 2015) in order "to answer the question of which stakeholders should be considered and... how much is at stake" (Falck \& Heblich, 2007). Therefore, an ex-ante selection activity conducted by company represents what Porter and Kramer called the "acid test" for assessing the presence or absence of an effective CSR strategy (Porter \& Kramer, 2006) which aims at addressing social issues, while providing the organization with some business benefits (Bhattacharyya et al., 2008).

To further grasp the opportunity of enriching the strategic management through the comprehension of challenges launched by CSR, it is necessary to draw attention to the governance modes of social responsibility initiatives (Husted, 2003; Husted et al., 2010; Nijhof et al., 2007; Porter \& Kramer, 2006). In particular, basic questions are how firms may organize the CSR? Which operational and strategic factors may drive the selection among different options? Which projects can be coherently managed internally given the company's boundaries?

According to Porter and Kramer (2006), the CSR organization implies the engagement of managers in a process aimed at identifying the social issues to focus on. Furthermore, in previous literature, the debate has been centred on the most appropriate collaboration strategy with non-governmental organizations (NGOs) or other non-profit institutions (Jonker \& Nijhof, 2006; Nijhof et al., 2007), and on interorganizational solutions for joint decision making and extensive cooperation forms with third parties along the company's value chain (Vurro et al., 2009). However, the discussion is still open and, probably, a more comprehensive response can be found amplifying the analysis to the conceptual constructs of the theory of the firm in order to deepen how companies may balance the social responsiveness with their efficient functioning as business units (McWilliams \& Siegel, 2001; Husted et al., 2010). In particular, given the complementarity existing in the organizational economics (Hoopes et al., 2003), transaction costs (Coase, 1937; Williamson, 1975), the agency problems (Fama \& Jensen, 1983; Jensen \& Meckling, 1976), and resource-based view (Barney, 1986; Barney, 1999) offer a background to understand how to reconcile the selection of suitable CSR governance modes with the fundamental function of economic wealth creation (Jensen, 2002). In this perspective, the organization of CSR actions represents an optimality problem that takes the form of a "make or by trade-off" (Husted \& Hallen, 2007).

As known, for a matter of efficiency, companies should tend to internalize those activities they are able to perform better than the market, leaving out of their organizational boundaries the initiatives that require resources not available or too costly to build internally. Moreover, in the perspective of agency, any transaction with third parties may subtend a conflict of interest that feeds opportunistic behaviours. Therefore, the internalization of CSR projects can be an option consistent with the target of optimal resources allocation as it 
contributes to mitigate the inefficiency caused by transaction and agency costs. Moreover, from a resource-based perspective, the option of in-house projects may subtend the leverage on intangible assets less imitable, in order to achieve competitive results not easily appropriable by third parties.

Between the extremes of market and hierarchy, other hybrid solutions may exist, with different degrees of leverage on internal resources or on external networks. Following the Husted's approach (2003), it is possible to distinguish among three governance modes, namely: the outsourcing, for example through charitable contributions; the partial externalization, through operational partnerships with other organizations; the internalization, through in-house projects that are designed and managed without the assistance of third parties. In terms of company involvement, the first option consists essentially in a transfer of financial resources from the firm to other organizations that care about specific social problems. Collaborative forms, instead, imply more complex interactions with third organizations in order to reap joint benefits from CSR initiatives. Finally, in the case of in-house projects, companies may opt for staying alone in planning and controlling CSR actions. Therefore, the first two forms belong to a more or less extensive external approach for organizing CSR initiatives ("buy" CSR), whereas the third form corresponds to an internal solution that embraces the organization, the execution, and the monitoring of CSR activities ("make" CSR).

Given the goal of containing costs and optimizing resources, a possible contribution to the solution of the make or buy trade-off between the internalization or the outsourcing of CSR may derive from the level of centrality of such initiatives. Indeed, centrality is a concept consistent with the strategic vision of CSR, as it is understood as the level of closeness and connection of CSR initiatives undertaken by the company with its core mission (Burke \& Logsdon, 1996; Husted \& Hallen, 2007; Husted et al., 2010).

In particular, from the centrality will depend the opportunity to exploit internal resources and capabilities necessary for a direct management of a CSR project. Moreover, from the centrality will depend the opportunity of relying on internal information and control systems for mitigating the agency problems underlying the CSR initiatives. As a result, in the case of in-house projects, the leverage on pre-existent organizational knowledge should increase, resulting in the reduction of delegation to third parties, and the economic incentives should be based on mechanisms of reward and penalty anchored to the monitoring systems already applied within the firm. On the other hand, when the company opts for externalization forms, the delegation to third parties should increase, the application of internal knowledge should decrease, whereas the economic incentives should be mainly based on the competition for financial resources (e.g.: donations) between external recipients.

Summarizing, if the CSR activities are closer to the company's core mis sion, agency problems and transaction costs can be mitigated by leveraging on organizational knowledge and internal monitoring systems. Conversely, if the CSR initiatives have less centrality to the company's core mission, then the application of governance forms involving a partial or a total outsourcing of these initiatives may be more likely, because of a potential lack of organizational knowledge and/or the inadequacy of internal control systems. Hence, resource availability, transaction costs, and firm capabilities may represent interconnected aspects underlying more or less extensive collaborative governance modes for CSR projects (Vurro et al., 2009).

\subsection{Stakeholder Management and CSR Governance Modes}

The approach based on the efficiency of costs and on the resources allocation contributes to make a progress in the understanding of modes through which a firm may decide to manage its social responsibility. However, it is not sufficiently clear as to what extent the decision to invest internally in CSR is connected with the stakeholder's needs that a company must prioritize. According to this perspective, for advancement in interpreting the CSR governance forms, the theoretical proposal of this study is to read the in-house modes also through the lens of the stakeholder management approach.

At a theoretical level, the link between the CSR and the stakeholder management is supported by the same definitions of CSR. In this regard, Epstein asserted that the "corporate social responsibility relates primarily to achieving outcomes from organizational decisions concerning specific issues or problems which have beneficial rather than adverse effects upon pertinent stakeholders" (Epstein, 1987). Years later, the concept of stakeholder responsibility coined by Freeman and Velamuri (2006) implies that the satisfaction of stakeholder groups can contribute to the legitimacy of a socially responsible company thanks to the creation of an enlarged value. Coherently with this position, Werther and Chandler (2010) recognize that "CSR addresses a company's relationships with its stakeholders". Therefore, as already argued by Carroll (1991), CSR fits well with the concept of organization's stakeholders that personalizes the idea of social responsibility by specifying groups or individuals that a company should consider within its projects (Dunfee, 2008). The opportunity, in fact, is to put "names and faces on the societal members who are most urgent to business, and to whom it must be responsive" 
(Carroll, 1991). Hence, the mapping of different stakeholder categories is necessary to confer more substance to the same CSR concept, which, alternatively, may be too vague for understanding its actual implications (Fassin, 2009; McWilliams et al., 2005). The latter is a really important matter as the stakeholder theory (Donaldson \& Preston, 1995; Freeman, 1984) provides a framework too large that draws the attention of scholars and managers on any group or individual who can affect or is affected by the achievement of the organization's objectives.

Therefore, a stakeholder management approach helps to better address a basic question frequently posed within problem solving cycles linked to CSR decisions (Ditlev-Simonson \& Midttun, 2011), such as: how to serve the different stakeholder groups (Falck \& Heblich, 2007; Neubaum et al., 2012; Nijhof et al., 2007; Park et al., 2014; Trapp, 2014). In this perspective, among the others, customers and human resources emerge as relevant stakeholders for any socially responsible company. In fact, even though external and internal respectively to organizational boundaries (Sirgy, 2002), customers and HR are both generally considered in literature as primary stakeholders (Carroll, 1993; Clarkson, 1995; Maon et al., 2009; Park \& Ghauri, 2014), given a significant impact on the achievement of core mission of the business. In fact, without their cooperation and support, it is acknowledged that the company may not survive (regarding the distinction between the different stakeholder groups, the challenge for the company's management is to ensure that the primary stakeholders achieve their objectives while the other stakeholders are also satisfied. However, as admitted by Carroll (1991), this "win-win" result is not always possible). Therefore, because of the direct linkage with the company's mission, their role is useful to corroborate the concept of centrality (Burke \& Logsdon, 1996) as key factor within the decisions of the CSR governance modes (Husted 2003; Husted et al., 2010). Moreover, human resources and customers are normative stakeholders (Phillips, 2003), because the organization has a direct moral obligation generally based on formal contracts. Finally, the strategic management of the relationship with customers and human resources may be the source of firm-specific intangible assets not always replaceable by other companies. This is a resource to be exploited and with respect to which the firm should not tend to lose its strategic and operational control.

\subsection{Hypotheses Development}

Human Resource and customers are both primary stakeholders that have a direct linkage with the core business. This is a general feature that should put them in the condition to incentivise the internalization of CSR activities targeted to their needs, even as safeguarding the corporate mission. So, the hypotheses about the impact of HR and customers on the internal governance solutions are further discussed.

Customers are able to exercise a relevant pressure on CSR initiatives, as this stakeholder category can strengthen or weaken the trust ties with the company on the belief that management is more or less socially responsible (Park et al., 2014). The low morality of managers acting as "bad guys" (Carroll, 2000), not only it's questionable, but, if perceived, it may be interpreted by customers also as scarce liability of goods and services of a company as well as its procedures. Therefore, the risk of harmful consequences on the market side is an additional incentive, respect to a normative one, for organizations to be compliant with CSR practices. This approach may contribute to the improvement of the social image and reputation of the company (Yoon et al., 2006). Indeed, the incorporation of CSR into marketing strategies of differentiation and advertising "helps to build a reputation of reliability and honesty concerning health, safety, ecology, and sustainable issues" (Carvalho et al., 2014).

Therefore, initiatives ensuring the quality and safety of products, the use of clear labelling, the transparency in the disclosure of information to customers, are all policies a company may directly manage with the aim to create a market goodwill anchored to the trust and the loyalty of customers. For better or for worse, all these aspects are amplified because of the diffusion of the information technology that allows customers access to much more information, or simple market rumours, than in the past. Customers can now move more quickly from one brand to another if they evaluate that the company's policies are not complying the CSR practices (Mishra \& Suar, 2010). The sensitive cases for both customers and firms have multiplied over the years, also thanks to the interest in CSR and its economic consequences given by media, governance authorities, markets, and consumer associations.

The following are some examples. In the mid-2000s, the withdrawal by Mattel of more than 20 million pieces of Fisher-Price toys and accessories for Barbie manufactured in China, because of the risk for consumers related to the use of paints with high lead content was sensational. In 2013, after a collapse of a factory in Bangladesh resulting in hundreds of deaths including children, Benetton had to intervene to avoid the group of "united colours" suffering speculative information with the risk of a significant drop of reputation. In Italy, Moncler had to disclose new information to its stakeholders after the decline $(-22 \%)$ of brand reputation within the social networks because of a journalistic report by Italian TV on the maltreatment of the geese for down jacke ts in the 
late 2014. In 2016, Samsung blocked the launch of the Galaxy Note 7, after the intervention of the American Commission on Consumer Safety, because of some battery burst. The company estimated the cost of the recall of the products as 5,3 billion dollars, even as hoping to regain the trust of consumers in the world. Moreover, confirming that tracking of the product as an important issue in the management of customer relations, at the end of 2016, the Italian Antitrust Commission fined Samsung for being guilty of opaque communications to customers with regard to the memory "rom" (reading only memory) of its smartphones and tablets. In early 2017, the stock price of FCA Automobiles dropped significantly on the financial markets (more than 5\% in Italy, with a peak of $-17 \%$ intraday at Wall Street) after the EPA (US Environment Protection Agency) accused the company of adopting software-altering harmful emissions. On the same line, the so-called Dieselgate of 2015 will cost for the Volkswagen Group several billions of dollars. It resulted in the change of the CEO of the first automotive group in the world.

The cases could increase, but what is briefly presented is sufficient to make clear the new challenges and threats that companies face for improving the reputation linked to the socially responsible manner by which they pursue their mission. Proactive behaviours and higher CSR standards may function as additional signals for enhancing the attractiveness of the business to the market (Park et al., 2014). This may be an incentive for the design of in-house projects in order to directly benefit from investments on the social reputation and reliability toward customers. Moreover, the opportunity of using the internal control systems already applied for evaluating the firm performance on the market and the company's capability to meet customer needs may represent an additional incentive that contributes to mitigate the distorting effects of agency problems underlying the CSR initiatives when the latter are mediated by third parties with respect to the final recipients.

Therefore, the first hypothesis is as follows:

H1. For CSR activities geared toward customers, internal governance modes (in-house projects) are more likely to occur than external governance modes (collaboration/total outsourcing).

In determining how a firm's activities should be managed, the organizational economics perspective is useful in developing human resource management policies. This is linked with the CSR. Employees and managers, in fact, are stakeholders whose goals and benefits are intertwined with the management of CSR. Their own values may drive social responsibility initiatives and their behaviour is influenced by the organizational culture of social responsiveness (Celma-Benaiges, Martinez-Garcìa \& Raya, 2016). Thanks to this reciprocal relationship, human resources may exert a significant pressure on CSR practices. At the same time, most competitive companies have interest to promote the imagine on the job market, leveraging directly on practices such as: the care of healthy and safe workplaces; the involvement of employees in company's management; the transparency of career policies; the safeguard of equal opportunities; the training and welfare of employees.

The business benefits expected, thanks to the CSR actions undertaken for improving the management of the relationships with HR, may range from a higher productivity (Park et al., 2014) to an enhanced reputation, which leads to an improved ability in attracting and retaining more skilled HR (Greening \& Turban, 2000; Lindgreen et al., 2009). This is confirmed by the increasing attention that companies and media confer to the monitoring of the attractiveness of workplaces. For example, in the ranking of the top 25 multinationals for the job quality, published by Great Place to Work Institute (2016), we can find leading companies such as Google in ICT, W. L. Gore \& Associates in the textiles, Adecco for professional services, Accor in the hospitality, 3M in manufacturing and production and American Express in the financial services.

Given the reciprocal influence between the company environment and people that collaborate to manage such organizations, cultural background and personal values may drive the orientation of CSR initiatives.

Several years of studies on strategic management emphasize the linkage between the values of a corporation and its strategy (Freeman \& Gilbert, 1988; Waddock \& Graves, 1997). Managers contribute to fuel this relationship when they are called to give the guidelines for assessing the salience of stakeholders to which the company has to be more or less responsive (Lindgreen et al., 2009; Mitchell et al., 1997; Park et al., 2014; Park \& Ghauri, 2014). Moreover, the same evolution of the internal control systems may support the informative cycle about actions oriented to improve goals and motivations of HR. A participatory leadership style, the application of monitoring policies going beyond a pure coercive approach, the control of coherence between skills and tas ks, the concern for gender issues and minorities or the attention to employee welfare, are all practises more frequently applied by more sensitive and advanced firms to improve the quality of HR management. Therefore, the fulfilment of contracts considered not only from a strictly economic point of view, but also psychological, becomes more productive to the extent that it strengthens the correlation between what the company expects from the employee and what the employee expects from the organization. 
If we recognize that the company's assets are also represented by the professionalism available within the organization and if we are aware that the competitive success requires the cooperation with and between stakeholders, then, as a consequence, companies should go beyond an approach to the conduct of HR based on a purely administrative system or on mechanisms of sanctions and commands. Therefore, the genesis of a climate of collaboration and consensus needs a direct involvement of hierarchies in defining management policies of HR not delegated to the market. If a pay-roll system can be outsourced with a low or a null risk to compromise the enhancement of human capital, practices such as the care of training, the quality of the workplace and career programs are all factors that fits well with CSR and that may confer a firm specific imprint in the management of HR. Here again, the final purpose can be the achievement of assets not easily imitable and less appropriable by third parties. Moreover, the mechanisms of responsibility and rewards already adopted by company within its internal systems of monitoring and incentives may contribute to mitigate the agency costs of CSR actions oriented to employees and managers. This can foster the use of in-house organizational modes for planning and controlling socially responsible initiatives aimed at HR.

Therefore, the second hypothesis is formalized as follows:

H2. For CSR activities geared toward human resources, internal governance modes (in-house projects) are more likely to occur than external governance modes (collaboration/total outsourcing).

The remainder of the paper is organized as follows. The next section contains the explanation of the methodology, including data gathering, variables definition and the regression models. The other sections illustrate and discuss the results of the study.

\section{Method}

\subsection{Data Gathering}

The empirical investigation is based on the observation of CSR initiatives disclosed through the social reports (also called CSR reports) published in 2012 by the Italian companies listed on the Dow Jones Sustainability Index Europe (DJSIE) in 2013.

The time period is consistent with the assumption of the financial constraint as an additional factor pushing on the reconciliation between economic and social value creation. Indeed, the time horizon includes the pro-cyclical effects produced by the last financial crisis (2007-2008) on the Italian economy during the years 2010-2012.

Italy is a country that is experiencing a growing attention of consumers and business toward socially sustainable behaviours linked to CSR policies. This phenomenon is well certified by the $23^{\circ}$ annual report of the Findomestic Observatory (2017), the largest company of consumer credit in Italy owned by BNP Paribas. In fact, the survey finds that $70 \%$ of consumers are willing to reward the products of companies, which are compliant to social and environmental responsibility. From the side of the companies, the $76 \%$ of them declares to have increased the commitment to social and environmental issues over the past five years. However, to the question of what hinders such commitment, the $80 \%$ of the surveyed companies highlight the lack of an immediate financial return (The Findomestic Observatory, 2017).

With reference to the panel, DJSIE includes the largest European companies in terms of sustainability and it is part of the Dow Jones Sustainability Index (DJSI), the longest running global benchmark for evaluating the performance of socially sustainable firms. Launched in 1999, this index is one of the main reference points for ethical and socially responsible investors, whereas the companies included are periodically evaluated on the basis of economic, social, and environmental performance (Triple Bottom Line). Therefore, the choice to refer to the DJSI offers the opportunity to focus on companies whose experience in CSR is "certified" by the inclusion in this special stock index. In addition, almost all $(90 \%)$ the companies extracted from the DJSIE declare to apply the Global Reporting Initiative (GRI) standard. This is an advantage in terms of structuring, clarity and homogeneity of social reports adopted by this study as source of information on the organizational approach to CSR.

In 2013, the Italian companies listed on DJSIE were 30, but the final set in this study consists of 19 firms because of the following reasons. One pure holding company has been excluded (-1), the same for one company with business unit in Italy but headquartered in Switzerland (-1). Two companies (-2) have been excluded as they published a sustainability report as addendum to the annual financial report, one of them from its 2013 report. One company has been excluded as it provides information on CSR, but within the social report of its parent company (-1). Finally, six companies have been not considered because they have not drawn up a social report in 2012 (-6). The sampled firms represent a variety of different industries such as energy, manufacturing, finance (insurance and banking) and other services. 
The analysed units consist of 483 CSR initiatives that are distributed according to the stakeholder-based classification of the social reports. This aspect contributes to make the analysis more objective and consistent with the message that the companies have sought to communicate through their social disclosure (Gangi \& D'Angelo, 2016).

On the basis of the information disclosed, the CSR initiatives have been classified according to their governance modes (see Appendix). Following the Husted's model (2003), the in-house projects are distinguished from those in cooperation or totally outsourced. In particular, a CSR initiative is classified "in-house" if, on the basis of the content of the social report, there is no reference to third organizations for the design and the implementation of the project. Instead, in case of externalization, a project is classified "in cooperation" if the social report describes the involvement of third parties that have carried out the project jointly with the firm. Phrases such as "in collaboration/cooperation with ..." or "the participation in ..." a specific project or workgroup with third parties, have been useful drivers in identifying projects carried out with other organizations. Moreover, in the case of outsourcing, the intervention of the company in a specific initiative is described as mainly financial. In fact, these are projects where the company provides funding to third institutions, scholarships or other forms of financial contributions. Therefore, consistently with the classification proposed by Husted (Husted et al., 2010), the external mode includes "both collaboration and pure external approach".

As in previous studies (Cormier \& Magnan, 2006), the classification follows a reliability process through the achievement of an inter-subjective judgment. In particular, in case of different opinions, these differences were discussed, thus obtaining a shared categorization of the CSR initiatives based on the features of the governance modes disclosed by firms within their social reports.

Summarizing, the procedure for the projects analysis has been articulated in the following steps: acquisition of the social reports; identification of projects addressed to the "customer" and "human resources" categories on the basis of the classification provided by the social reports; reading of the descriptive content of projects; classification of projects between in-house or outsourced (partially or totally).

\subsection{Variables and Models of Analysis}

After a descriptive statistic, the hypotheses have been tested through logistic regressions. In particular, the dependent variable is a dummy called "In-house project" that is equal to 1 if the CSR initiative is internalized (in-house), whereas it takes value 0 if the project is run in collaboration or totally outsourced (externalization).

To test the relationship between customers and the CSR governance forms, the regression analysis adopts a dummy called "Customers" as independent variable, which is equal to 1 , if the projects are addressed to this stakeholder group, equal to 0 otherwise. Moreover, to evaluate the impact of HR on the governance mode, the regression analysis considers another dummy independent variable called "HR", which is equal to 1 , if the projects are addressed to HR (employees and/or managers), equal to 0 otherwise.

Consistently with previous investigations (Husted et al., 2010), the study controlled for several factors considered as determinants of CSR, such as the firm size, the foreign ownership, and the multinational model of the company (model 1). In addition, following a stepwise approach, the study considers other two variables to control for industry (model 2) and the self-financing capacity (model 3).

Therefore, the variable "Size" measures the size of the company as the logarithm of the number of employees. The variable "Ownership" measures the relevant percentage held by foreign shareholders under the Regulation of the Italian Commission for Companies and Stock Exchange. The variable "Multinational" is a dummy that takes value 1 if the company is a multinational and value 0 otherwise. By "Industry", this study intends industry category dummies to control for: manufacturing $(Y e s=1 ; \operatorname{Not}=0)$, energy $($ Yes $=1 ;$ Not $=0)$ and finance $($ Yes $=$ 1; Not =0). Finally, the variable "Cash-Flow/Sales" measures the incidence of cash flow on revenues at 2010 (t-1). The latter is a proxy of slack financial resources that for literature is an incentive to invest in social performance (Orlitzky et al., 2003; Waddock \& Graves, 1997).

The regression models are formalized as follows:

Model 1: In-house project $=\beta_{1} \mathrm{HR}+\beta_{2}$ Customers $+\beta_{3}$ Size $+\beta_{4}$ Ownership $+\beta_{5}$ Multinational

Model 2: In-house project $=\beta_{1} \mathrm{HR}+\beta_{2}$ Customers $+\beta_{3}$ Size $+\beta_{4}$ Ownership $+\beta_{5}$ Multinational $+\beta_{6}$ Industry.

Model 3: In-house project $=\beta_{1} \mathrm{HR}+\beta_{2}$ Customers $+\beta_{3}$ Size $+\beta_{4}$ Ownership $+\beta_{5}$ Multinational $+\beta_{6}$ Industry + $\beta_{7}$ Cashflow/Sales.

Given the hypotheses, a positive relationship between the dependent variable and the variables "HR" and "Customers" is expected. 


\section{Results}

\subsection{Descriptive Statistics}

Table 1 shows several descriptive statistics. HR represent 34\% of CSR initiatives (163 projects) and customers cover $15 \%$ of the samples (73 initiatives), while $51 \%$ of the projects are oriented toward other interest groups, such as the community or the environmental stakeholders (247 projects). Therefore, the stakeholder categories under investigation represent the $49 \%$ of all the projects.

Table 1. Descriptive statistics

\begin{tabular}{|c|c|c|}
\hline Governance modes & Projects $\left(n^{\circ}\right)$ & $\%$ \\
\hline In house & 250 & $52 \%$ \\
\hline Collaboration & 125 & $26 \%$ \\
\hline Outsourcing & 108 & $22 \%$ \\
\hline Total & 483 & $100 \%$ \\
\hline Stakeholders & Projects $\left(n^{\circ}\right)$ & $\%$ \\
\hline Human Resources & 163 & $34 \%$ \\
\hline Customers & 73 & $15 \%$ \\
\hline Other & 247 & $51 \%$ \\
\hline Total & 483 & $100 \%$ \\
\hline Stakeholders & $\begin{array}{c}\text { Internal Governance mode }\left(\mathrm{n}^{\circ}\right. \\
\text { projects })\end{array}$ & $\begin{array}{c}\text { External Governance mode }\left(\mathbf{n}^{\circ}\right. \\
\text { projects })\end{array}$ \\
\hline Human Resources & 127 & 36 \\
\hline Customers & 50 & 23 \\
\hline Other & 73 & 174 \\
\hline Total & 250 & 233 \\
\hline Stakeholders & Internal Governance mode (\%) & External Governance mode (\%) \\
\hline Human Resources & $51 \%$ & $15 \%$ \\
\hline Customers & $20 \%$ & $10 \%$ \\
\hline Other & $29 \%$ & $75 \%$ \\
\hline Total & $100 \%$ & $100 \%$ \\
\hline
\end{tabular}

In-house initiatives amount to 250 (the $52 \%$ of the total sample). With regard to HR, the number of projects managed internally by companies is equal to 127 (51\% of the total in-house projects). Customers, instead, cover $20 \%$ of the internal initiatives (50 projects). The remaining in-house projects (73 initiatives) are targeted to other stakeholder categories.

Looking at the external governance modes, the number of projects oriented toward HR is equal to 36, with an incidence of $15 \%$. Customers, instead, represent the $10 \%$ of the total initiatives managed partially or totally in outsourcing. Therefore, 174 initiatives (75\% of the total projects undertaken in collaboration or in outsourcing) are targeted to other stakeholders.

Summarizing, internal governance forms are more frequent when compared with HR and customers, whereas, the recourse to hybrid solutions or outsourcing modes is more frequent when compared to other interest groups such as the environmental stakeholders.

\subsection{Regression Analysis}

The logistic regression allows analysing the relationship between the CSR governance modes and the stakeholder categories under investigation by introducing some control variables. Goodness-of-fit measures for logistic regressions (overall percentage, Cox \& Snell R-square, Nagelkerke R- square, Hosmer-Lemeshow Test) indicate that all the econometric models fit well the data.

Results provide support for the research assumptions (see Table 2). In particular, all the econometric models demonstrate that $\mathrm{HR}$ is a stakeholder category that has a positive impact on the company's decision to internalize CSR projects. The estimates return the same results also in the case of customers that appear to be a positive predictor for in-house governance modes. Therefore, the multivariate analysis confirms both the first (H1) and the second $(\mathrm{H} 2)$ research hypothesis about the role that the primary stakeholder categories under investigation may have for the solution of a "make-or-buy" trade-off within the organizational economics of CSR.

Moreover, with reference to the control variables, the logistic regressions show the multinational business model as an additional positive predictor of in-house projects. Probably, companies placed in different national contexts tend to internalize CSR initiatives toward HR and customers in order to exploit synergies deriving from the application of operational standards that help to create one image and a stronger identity as a socially responsible firm everywhere it operates. 
Table 2. Regression analysis

\begin{tabular}{|c|c|c|c|c|c|c|c|c|c|}
\hline \multirow{3}{*}{ Inde pe nde nt variables } & \multicolumn{3}{|c|}{ Model 1} & \multirow{2}{*}{\multicolumn{3}{|c|}{$\begin{array}{c}\text { Model 2 } \\
\text { Dependent variable: } \\
\text { In-house project }\end{array}$}} & \multirow{2}{*}{\multicolumn{3}{|c|}{$\begin{array}{l}\text { Model 3 } \\
\text { endent variable: } \\
\text { l-house project }\end{array}$}} \\
\hline & \multicolumn{3}{|c|}{$\begin{array}{l}\text { Dependent variable: } \\
\text { In-house project }\end{array}$} & & & & & & \\
\hline & B coeff. & $\begin{array}{c}\text { Standard } \\
\text { Error }\end{array}$ & Wald & B coeff. & $\begin{array}{l}\text { Standard } \\
\text { Error }\end{array}$ & Wald & B coeff. & $\begin{array}{l}\text { Standard } \\
\text { Error }\end{array}$ & Wald \\
\hline Constant & $-3,526 * * *$ & 1,136 & 9,636 & $-3,392 * * *$ & 1,170 & 8,411 & $-2,872 * *$ & 1,419 & 4,097 \\
\hline HR & $2,174 * * *$ & 0,240 & 82,412 & $2,167 * * *$ & 0,241 & 80,872 & $2,165 * * *$ & 0,241 & 80,698 \\
\hline Customers & $1,842 * * *$ & 0,304 & 36,706 & $1,848 * * *$ & 0,305 & 36,717 & $1,832 * * *$ & 0,306 & 35,892 \\
\hline Size & 0,424 & 0,29 & 2,143 & 0,326 & 0,294 & 1,223 & 0,243 & 0,322 & 0,569 \\
\hline Ownership & 0,001 & 0,036 & 0,001 & 0,016 & 0,043 & 0,138 & 0,013 & 0,043 & 0,096 \\
\hline Multinational & $0,752 * *$ & 0,377 & 3,982 & $0,775^{*}$ & 0,427 & 3,125 & $0,829 *$ & 0,443 & 3,506 \\
\hline Cash Flow/Sales $_{(\mathrm{t}-1)}$ & & & & & & & $-0,712$ & 1,099 & 0,42 \\
\hline Industry & & & & YES & & & YES & & \\
\hline $\mathrm{N}^{\circ}$ of observations & 483 & & & 483 & & & 483 & & \\
\hline -2 Log likelihood & 550,012 & & & 548,696 & & & 548,275 & & \\
\hline Cox \& Snell R-Square & 0,218 & & & 0,220 & & & 0,221 & & \\
\hline Negelkerke R-Square & 0,291 & & & 0,294 & & & 0,295 & & \\
\hline Overall percentage & 72,700 & & & 72,700 & & & 72,700 & & \\
\hline $\begin{array}{l}\text { Hosmer and Lemeshow } \\
\text { Test: }\end{array}$ & & & & & & & & & \\
\hline Chi-square & 2,207 & & & 7,363 & & & 5,652 & & \\
\hline Sig. & 0,974 & & & 0,498 & & & 0,686 & & \\
\hline
\end{tabular}

Significantlevel: $1 \%(* * *) ; 5 \%(* *) ; 10 \%(*)$

\section{Discussion}

Over the years, the question of how to reconcile CSR efforts with the creation of economic value has acquired higher intensity. The debate triggered by the Friedman's proposition (1970) has engaged scholars and practitioners researching the link between the economic and social functions of the firm. This complex objective was again questioned because of the long-term effects of an extraordinary international financial crisis that contributed to reinforce the vision of CSR as business case. The latter, has required a renewed focus on the priorities that the company should adopt in the definition of objectives and resources to invest in CSR programs. With regard to these aspects, the selection of suitable organizational modes represents a relevant topic for the aim of the firm to reap benefits from CSR, simultaneously achieving its core mission (Bansal et al., 2015).

Starting from the Husted' taxonomy $(2003,2010)$, this article has sought a further understanding of the choice to internalize CSR activities. In particular, through the perspective of stakeholder management, the study verified if HR and customers could be considered as drivers of in-house projects. Both these stakeholders, in fact, are salient for a company, as it cannot survive without their cooperation and support. Moreover, HR and customers generally act on the basis of formal contracts and this circumstance allows them to exert a more direct pressure on firm decisions. However, even if normative, the interaction with these stakeholders is not only transactional, but also relational (Hillman \& Keim, 2001). Given their linkage with the core mission, companies tend to mobilize the organizational skills and internal control systems in order to create a sustainable competitive advantage in the long run. For this reason, the option to apply internal resources represents a strategic opportunity and an economic incentive for deploying in-house projects. On one hand, the compliance with social responsibility toward employees and customers offers the opportunity to engage in firm-specific activities less imitable by competitors and less appropriable by third parties. On the other hand, the combination between internal competences and internal monitoring systems provides opportunity to mitigate transaction and agency costs eventually underlying the external governance modes.

By confirming the research hypotheses, findings are also consistent with previous investigations that show the positive influence of CSR on consumers purchase intention and brand loyalty (Deng \& $\mathrm{Xu}, 2017)$. Moreover, the empirical results of the study are in line with earlier analyses that highlight how the perceived corporate social responsibility has a significant and positive relationship with the work environment in terms of attraction and retention of higher quality employees (Greening \& Turban, 2000), job satisfaction and organizational commitment (Asrar-ul-Haq, Kuchinke \& Iqbal, 2017). As a whole, these are intangible assets representing the potential outputs of a more pragmatic approach to the meta-objective of a shared value creation (Porter \& Kramer, 2006; Porter \& Kramer, 2011).

The article has several theoretical implications. First, it suggests that the principles of the stakeholder management may improve the comprehension of the organizational responsibilities necessary to carry on 
in-house projects, which result in a structural configuration of CSR within corporate organization. Second, by applying the stakeholder management perspective to the field of the organizational economics of CSR, the paper further contributes to advance both these research streams. Third, given their linkage with the core mission, the role of HR and customers stimulates new insights about the concept of centrality as driver of internal CSR governance modes.

The study has some limitations that require mentioning. The first limit regards the results generalization because the study has been conducted on a specific geographical context of companies. Second, the application of a bimodal distribution of projects (internal or external), even if consistent with the structure of corporate social disclosure, may lose details that could be obtained through complementary or additional tools such as a survey to managers of sampled companies. Third, further analysis on the CSR governance modes might deepen the specific object of CSR initiatives. Therefore, at this step, findings provide useful insights on the relationship between organizational economics of CSR and the stakeholder management, but there remain additional interesting questions for future streams of research.

\section{References}

Asrar-ul-Haq, M., Kuchinke, K. P., \& Iqbal, A. (2017). The relationship between corporate social responsibility, job satisfaction, and organizational commitment: Case of Pakistani higher education. Journal of Cleaner Production, 142, 2352-2363. https://doi.org/10.1016/j.jclepro.2016.11.040

Bansal, P., Guoliang, F. J., \& Jung J. C. (2015). Managing responsibly in tough economic times: strategic and tactical CSR during the 2008-2009 global recession. Long Range Planning, 48, 69-79. https://doi.org/10.1016/j.lrp.2014.07.002

Barney, J. B. (1986). Strategic factor markets, expectation, luck and business strategy. Management Science, 32(10), 1231-1241. https://doi.org/10.1287/mnsc.32.10.1231

Barney, J. B. (1999). How firm's capabilities affect boundary decisions. Sloan Management Review, 40(3), 137-145.

Best Place to Work Institute. (2016). World's Best Multinational Workplace.

Bhattacharyya, S. S., Sahay, A., Pratap, A., \& Chaturvedi, A. (2008) A toolkit for designing firm level strategic corporate social responsibility (CSR) initiatives. Social Responsibility Journal, 4(3), 265-282. https://doi.org/10.1108/17471110810892802

Burke, L., \& Logsdon, J. M. (1996). How corporate social responsibility pays off. Long Range Planning, 29(4), 495-502. https://doi.org/10.1016/0024-6301(96)00041-6

Carroll, A. (1991). The pyramid of corporate social responsibility: toward the moral management of organizational stakeholders. Business Horizons, 4, 39-48. https://doi.org/10.1016/0007-6813(91)90005-G

Carroll, A. (1993). Business and Society. Ethics and Stakeholder Management. South Western Publishing Co., Cincinnati.

Carroll, A. (2000). Ethical challenges for business in the new millennium: corporate social responsibility and models of management morality. Business Ethics Quarterly, 10(1), 33-42. https://doi.org/10.2307/3857692

Carvalho, J. M. S., Jonker, J., \& Dentchev, N. (2014). What's in a word? An exploration of the changes in meaning of corporate social responsibility over the last century with an emphasis on the last decades, in Turker, D., Toker, H, \& Altuntas, C. (Eds.), Contemporary issues in corporate social responsibility, Lexington Books.

Celma-Benaiges, M. D., Martinez-Garcìa, E., Raya, J. (2016). An Analysis of CSR in Human Resource Management Practices and Its Impact on Employee Job Satisfaction in Catalonia, Spain. European Accounting and Management Review, 3(1), 45-71.

Clarkson, M. B. E. (1995). A stakeholder framework for analysing and evaluating corporate social performance. Academy of Management Review, 20(1), 92-117.

Coase, R. (1937). The nature of the firm. Economica, 4, 386-405. https://doi.org/10.1111/j.1468-0335.1937.tb00002.x

Cormier, D., \& Magnan, M. (2006). The revised contribution of environmental reporting to investors' valuation of a firm's earnings: an international perspective. Ecological Economics, 62, 613-626. https://doi.org/10.1016/j.ecolecon.2006.07.030 
Deng, X., \& Xu, Y. (2017). Consumers' Responses to Corporate Social Responsibility Initiatives: The Mediating Role of Consumer-Company Identification. Journal of Business Ethics, 142(3), 515-526. https://doi.org/10.1007/s10551-015-2742-x

Ditlev-Simonson, C. D., \& Midttun, D. (2011). What motivates managers to pursue corporate responsibility? A survey among key stakeholders. Corporate Social Responsibility and Environmental Management, 18, 25-38. https://doi.org/10.1002/csr.237

Donaldson, T., \& Preston, L. E. (1995). The stakeholder theory of the corporation: concepts, evidence and implications. Academy of Management Review, 20(1), 65-91.

Dunfee, T. W. (2008). Stakeholder theory: managing Corporate Social Responsibility in a multiple actor context. In Crane, A., McWilliams, A., Matte, D., Moon, J., \& Siegel, D. Corporate Social Responsibility, Oxford University Press, Oxford.

Epstein, M. E. (1987) The corporate social policy process: beyond business ethics, corporate social responsibility and corporate social responsiveness. California Management Review, 99, 29-114. https://doi.org/10.2307/41165254

Falck, O., \& Heblich, S. (2007). Corporate social responsibility: doing well by doing good. Business Horizons, 50, 247-254. https://doi.org/10.1016/j.bushor.2006.12.002

Fama, E. F., \& Jensen, M. C. (1983). Separation of ownership and control. Journal of Law and Economics, 26(2), 301-325. https://doi.org/10.1086/467037

Fassin, Y. (2009). The stakeholder model refined. Journal of Business Ethics, 84, 113-135. https://doi.org/10.1007/s10551-008-9677-4

Freeman, R. E. (1984), Strategic management: a stakeholder approach. Boston, Pitman.

Freeman, R. E., \& Gilbert, D. R. (1988). Corporate strategy and the search for ethics. Prentice-Hall, Englewood Cliffs, NJ.

Freeman, R. E., \& Velamuri, S. R. (2006). A new approach to CSR: company, stakeholder, responsibility. In Kakabadse, A., \& Morsine, M., (eds.). Corporate Social Responsibility: reconciling aspiration with application, Palgrave McMillan, London. https://doi.org/10.1057/9780230599574_2

Friedman, M. (1970). The social responsibility of business is to make profits, New York Time Magazine, September 13th.

Gangi, F., \& D'Angelo, E. (2016). The Virtuous Circle of Corporate Social Performance and Corporate Social Disclosure. Modern Economy, 7, 1396-1418. https://doi.org/10.4236/me.2016.712129

Greening, D. W., \& Turban, D. B. (2000). Corporate social performance as a competitive advantage in attracting a quality workforce. Business and Society, 39, 254-280. https://doi.org/10.1177/000765030003900302

Harris, J. D., \& Freeman, R. E. (2008). The impossibility of the separation thesis. Business Ethics Quarterly, 18(4), 541-548. https://doi.org/10.5840/beq200818437

Hillman, C. E., \& Keim, G. D. (2001). Shareholder value, stakeholder management and social issues: what's the bottom line? Strate gic Management Journal, 22, 125-139. https://doi.org/10.1002/1097-0266(200101)22:2<125::AID-SMJ150>3.0.CO;2-H

Hoopes, D., Madsen, T., \& Walker, G. (2003). Guest editors'introduction to the special issue: why is there a resource-based view? Toward a theory of competitive heterogeneity. Strategic Management Journal, 24, 889-902. https://doi.org/10.1002/smj.356

Husted, B. W. (2003). Governance choices for corporate social responsibility: to contribute, collaborate or internalize. Long Range Planning, 36, 481-498. https://doi.org/10.1016/S0024-6301(03)00115-8

Husted, B. W., \& Allen, D. B. (2007). Strategic corporate social responsibility and value creation among large firms. Long Range Planning, 40, 594-610. https://doi.org/10.1016/j.lrp.2007.07.001

Husted, B. W., Allen, D. B., \& Rivera, J. E. (2010). Governance choice for strategic corporate social responsibility, Evidence from Central America. Business and society, 49(2), 201-215. https://doi.org/10.1177/0007650308315504

Jensen M. C. (2002). Value maximization, stakeholder theory and the corporate objective function. Business Ethics Quarterly, 12(2), 235-256. https://doi.org/10.2307/3857812 
Jensen, M. C., \& Meckling, W. H. (1976). Theory of the firm: Managerial behaviour, agency costs and ownership structure. Journal of Financial Economics, 4(3), 305-360. https://doi.org/10.1016/0304-405X(76)90026-X

Jonker, J., \& Nijhof, A. (2006). Looking through the eyes of the other: assessing mutual expectations and experiences in order to shape dialogue and collaboration between business and NGOs with respect to CSR. Corporate Governance: An International Review, 14, 456-466. https://doi.org/10.1111/j.1467-8683.2006.00518.x

Kurucz, E.C., Colbert, B.A., \& Wheeler, D. (2008). The business case for corporate social responsibility. In Crane, A., McWilliams, A., Matten, D., Moon, J., \& Siegel, D., (EDS.). The Oxford Handbook of Corporate Social Responsibility, 83-110, Oxford University Press, New York.

Lindgreen, A., Swan, V., \& Johnson, W. J. (2009). Corporate social responsibility: an empirical investigation of U.S. organizations. Journal of Business Ethics, 85, 303-323. https://doi.org/10.1007/s 10551-008-9738-8

Maon, F., Lindgreen, A., \& Swaen, V. (2009). Designing and implementing corporate social responsibility: an integrative framework grounded in theory and practice. Journal of Business Ethics, 87, 71-89. https://doi.org/10.1007/s10551-008-9804-2

McWilliams, A., \& Siegel, D. S. (2001). Corporate social responsibility: a theory of the firm perspective. Academy of Management Review, 26(1), 117-127.

McWilliams, A., Siegel, D. S., \& Wright, P. M. (2005). Corporate social responsibility: strategic implications. Working Papers in Economics, Rensselaer, N0506, May, 1-31.

Mishra, S., \& Suar, D. (2010). Does corporate social responsibility influence firm performance of Indian companies? Journal of Business Ethics, 95, 571-601. https://doi.org/10.1007/s 10551-010-0441-1

Mitchell, R. K., Agle, B. R., \& Wood, D. J. (1997). Toward a theory of a stakeholder identification and salience: defining the principle of who and what really counts. Academy of Management Review, 22 (4), 853-886.

Neubaum, D. O., Dibrell, C., \& Craig, J. B. (2012). Balancing natural environmental concerns of internal and external stakeholders in family and non-family businesses. Journal of Family Business Strategy, 3, 28-37. https://doi.org/10.1016/j.jfbs.2012.01.003

Nijhof, A., Brujin, T., \& Honders, H. (2007). Partnerships for corporate social responsibility. A review of concepts and strategic options. Management Decision, 46(1), 152-167. https://doi.org/10.1108/00251740810846798

Orlitzky, M., Schmidt, F. L., \& Rynes, S. L. (2003). Corporate social and financial performance: a Meta-analysis. Organization Studies, 24(3), 403-441. https://doi.org/10.1177/0170840603024003910

Park, B. I., \& Ghauri, P. N., (2014). Determinants influencing CSR practices in small and medium sized MNE subsidiaries: a stakeholder perspective. Journal of World Business. https://doi.org/10.1016/j.jwb.2014.04.007

Park, B. I., Chidlow, A., \& Choi, J. (2014). Corporate social responsibility: stakeholders influence on MNEs activities. International Business Review, 23, 996-980. https://doi.org/10.1016/j.ibusrev.2014.02.008

Peloza, J. (2006). Using corporate social responsibility as insurance for financial performance. California Management Review, 80, 48-58. https://doi.org/10.2307/41166338

Phillips, R. (2003). Stakeholder legitimacy. Business Ethics Quarterly, 13(1), 25-41. https://doi.org/10.5840/beq20031312

Porter, M. E., \& Kramer, M. R. (1999). Philanthropy's new agenda: creating value. Harvard Business Review, November-December, 121-130.

Porter, M. E., \& Kramer, M. R. (2006). Strategy and society: the link between competitive advantage and corporate social responsibility. Harvard Business Review, December 1-13.

Porter, M. E., \& Kramer, M. R. (2011). Creating sharing value. Harvard Business Review, January-February, 3-17.

Salazar, J., \& Husted, B. (2008). Principal and agents: further thoughts on the Friedmanite critique of Corporate Social Responsibility. In Crane, A., McWilliams, A., Matten, D., Moon, J., \& Siegel, D., (EDS.), The Oxford Handbook of Corporate Social Responsibility, 83-110, Oxford University Press, Oxford, UK.

Sirgy, M. J. (2002). Measuring corporate performance by building on the stakeholders model of business ethics. 
Journal of business ethics, 35(3), 143-162. https://doi.org/10.1023/A:1013856421897

The Findomestic Observatory, Consumption, 2016.

The UN Global Compact-Accenture CEO Study on Sustainability, 2013.

Trapp, N. L. (2014). Stakeholder involvement in CSR strategy-making? Clues from sixteen Danish companies. Public relations Review, 40, 42-49. https://doi.org/10.1016/j.pubrev.2013.11.005

Vurro, C., Russo, A., \& Perrini, F. (2009). Shaping sustainable value chains: network determinants of supply chain governance models. Journal of Business Ethics, 90, 607-621. https://doi.org/10.1007/s10551-010-0595-x

Waddock, S. A., \& Graves, S. B. (1997). The corporate social performance - financial performance link. Strategic Management Journal, 18(4), 303-319. https://doi.org/10.1002/(SICI)1097-0266(199704)18:4<303::AID-SMJ869>3.0.CO;2-G

Werther, W. B., \& Chandler, D. (2010). Strategic corporate social responsibility. Stakeholders in a global environment. Sage Publications, London.

Williamson, O. E. (1975). Markets and hierarchies: Analysis and antitrust implication. Free Press, New York.

Yoon, Y., Canli, Z. C., \& Schwarz, N. (2006). The effect of corporate social responsibility (CSR) activities on companies with bad reputations. Journal of Consumer Psychology, 16(4), 377-390. https://doi.org/10.1207/s15327663jcp1604_9

Appendix: Examples of CSR initiatives and governance modes

\begin{tabular}{|c|c|c|c|c|c|c|c|c|}
\hline \multirow[b]{2}{*}{$\begin{array}{l}\text { Stakeholder } \\
\text { categories }\end{array}$} & \multicolumn{4}{|c|}{$\begin{array}{c}\text { Internalization } \\
\text { (in-house projects) }\end{array}$} & \multicolumn{4}{|c|}{$\begin{array}{c}\text { Externalization } \\
\text { (collaboration/outsourcing) }\end{array}$} \\
\hline & $\begin{array}{c}\text { CSR } \\
\text { initiatives } \\
\end{array}$ & Description & Industry & Firm & $\begin{array}{c}\text { CSR } \\
\text { initiatives } \\
\end{array}$ & Description & Industry & Firm \\
\hline HR & $\begin{array}{l}\text { "Gender } \\
\text { Balance" }\end{array}$ & $\begin{array}{l}\text { for equal } \\
\text { opportunities } \\
\text { between men } \\
\text { and women, } \\
\text { which was } \\
\text { started with a } \\
\text { survey of the } \\
\text { situation } \\
\text { existing in the } \\
\text { various Group } \\
\text { companies }\end{array}$ & Finance & Generali & "Play Safe" & $\begin{array}{l}\text { in collaboration } \\
\text { with Explora - } \\
\text { Children's Museum } \\
\text { of Rome, was } \\
\text { launched } \\
\text { project "Play Safe: } \\
\text { the game is a } \\
\text { serious matter." } \\
\text { The training } \\
\text { initiative directed } \\
\text { at non-operational } \\
\text { personnel, has } \\
\text { dealt with the key } \\
\text { issues of security }\end{array}$ & Energy & Enel \\
\hline Customers & $\begin{array}{c}\text { "Tyre } \\
\text { Campus" }\end{array}$ & $\begin{array}{l}\text { excellence in } \\
\text { product } \\
\text { training, both } \\
\text { in terms of } \\
\text { content and } \\
\text { methods, from } \\
\text { factory visits to } \\
\text { simulations on } \\
\text { tire } \\
\text { performance, } \\
\text { information } \\
\text { and training to } \\
360 \text { degrees }\end{array}$ & $\begin{array}{c}\text { Manufact } \\
\text { uring }\end{array}$ & Pirelli & $\begin{array}{l}\text { "ITU Child } \\
\text { on line } \\
\text { protection" }\end{array}$ & $\begin{array}{l}\text { participation in the } \\
\text { working group } \\
\text { coordinated by } \\
\text { ITU (International } \\
\text { Telecommunicatio } \\
\mathrm{n} \text { Union) for the } \\
\text { preparation of a } \\
\text { guideline on } \\
\text { "Child Online } \\
\text { Protection - COP" } \\
\text { aimed at } \\
\text { companies in the } \\
\text { broadcasting, } \\
\text { internet and mobile } \\
\text { industries }\end{array}$ & Services & Telecom \\
\hline
\end{tabular}

\section{Copyrights}

Copyright for this article is retained by the author(s), with first publication rights granted to the journal.

This is an open-access article distributed under the terms and conditions of the Creative Commons Attribution license (http://creativecommons.org/licenses/by/4.0/). 